\title{
Ghrelin: New Molecular Pathways Modulating Appetite and Adiposity
}

\author{
Ruben Nogueiras ${ }^{a, b} \quad$ Lynda M. Williams ${ }^{c} \quad$ Carlos Dieguez $^{a, b}$ \\ ${ }^{\text {a }}$ Department of Physiology, School of Medicine - Instituto de Investigacion Sanitaria (IDIS), University of Santiago de Compostela, \\ ${ }^{\mathrm{b}}$ CIBER Fisiopatología de la Obesidad y Nutrición (CIBERobn), Santiago de Compostela (A Coruña), Spain \\ ${ }^{c}$ Obesity and Metabolic Health Division, Rowett Institute of Nutrition and Health, University of Aberdeen, UK
}

\section{Keywords}

Ghrelin · Bsx · GOAT · Food intake

\section{Summary}

Ghrelin is a unique endogenous peptidic hormone regulating both hunger and adiposity. Many of the actions of ghrelin are modulated specifically by the central nervous system. A number of molecular events triggered via the activation of the ghrelin receptor (GHS-R1a), leading to increased levels of neuropeptide $Y$ (NPY) and agoutirelated peptide (AgRP) and ultimately responsible for the orexigenic effect of ghrelin have been characterized. Moreover, the discovery of ghrelin O-acyltransferase (GOAT), the enzyme responsible for the octanoylation of ghrelin, provides a mechanism allowing specific targeting of the ghrelin/GHS-R1a system without affecting the role of des-acyl-ghrelin in other pathways involved in the regulation of energy balance. This review aims to summarize novel roles of ghrelin in energy balance, focusing particularly on both the newly identified neuronal pathways mediating the effects of ghrelin and on peripheral mechanisms leading to increased adiposity.

\section{Introduction}

In 1999, ghrelin was identified as the endogenous ligand of the growth hormone secretagogues-receptor (GHS-R), with the highest activity found in stomach extracts [1]. The ligand took its name from the proto-Indo-European word 'ghre,' which means grow, and 'relin,' relating to its growth hormone $(\mathrm{GH})$ releasing activities. A short time later, an independent group identified a similar peptide from the stomach, termed motilin- related peptide [2]. Ghrelin and motilin-related peptide have a very high homology and due to the similarity in structure and action are considered as a novel gastrointestinal hormone family.

The ghrelin precursor, preproghrelin, is 117 amino acids long and gives rise to the ghrelin peptide, consisting of 28 amino acids with an n-octanoylated serine in position 3. After the discovery of the 28 amino acid ghrelin, several other isoforms produced by alternative splicing of the ghrelin gene were found, the most abundant form being des-acylated (des[Gln14)]) ghrelin (des-acyl-ghrelin), constituting approximately $80-90 \%$ of total circulating ghrelin. Des-acyl-ghrelin appears to have cardioprotective, antiproliferative and adipogenic properties, and can antagonize octanoyl-ghrelin-induced effects on insulin secretion and blood glucose levels in humans [3]. Des-acyl-ghrelin does not activate GHS-R1a and therefore cannot cross over with the endocrine activities of octanoylated ghrelin, however there is some controversy surrounding potential GHS-R1a-independent endocrine activities. There is growing evidence that alternative receptors for acylated and/or des-acylated ghrelin exist that may predominantly mediate non-endocrine or paracrine effects [4-7]. Recently, a 23-amino acid ghrelin-associated peptide was discovered and named obestatin [8]. An initial report showed that peripheral and central administration of obestatin antagonized the effects of ghrelin on food intake, body weight and gastric emptying, but had no effect on growth hormone levels [8]. Furthermore, treatment with obestatin led to a sustained suppression of gastric emptying activity. However, further studies using both central and peripheral injections of obestatin did not find any influence on food intake, body weight gain, gastric transit, gastrointestinal motility and gastric vagal afferent activity in rats or mice [9-12]. Therefore, the biological role of obestatin is still controversial, and its potential as an anti-obesity drug target is doubtful.

\section{KARGER}

Fax +497614520714

Information@Karger.de

www.karger.com (c) 2010 S. Karger GmbH, Freiburg

Accessible online at:

www.karger.com/ofa
Ruben Nogueiras, $\mathrm{PhD}$

Department of Physiology, School of Medicine - Instituto de Investigaciones Sanitarias (IDIS) University of Santiago de Compostela and CIBER Fisiopatología de la Obesidad y la Nutrición (CIBERobn)

S. Francisco s/n, 15782, Santiago de Compostela (A Coruña), Spain

ruben.nogueiras@usc.es 
Despite its presence in other tissues, ghrelin is produced primarily in the stomach, with approximately $65 \%$ of plasma ghrelin levels coming from this tissue, where ghrelin is produced by the X/A-like cells within the oxyntic glands of the gastric fundus mucosa. However, the small intestine, brain, hypothalamus, pituitary, pancreas, kidney, lymphocytes, lung, placenta, testis and ovary also express ghrelin [13, 14]. Consistent with its wide distribution, ghrelin is involved in diverse biological actions in addition to increasing appetite and $\mathrm{GH}$ secretion. These include, reproduction, tumor development, glucose metabolism and the immune response. Indeed, the majority of ghrelin comes from peripheral tissues, but its central actions are of great importance. It is unclear how much ghrelin derived from the periphery may reach neurons within the central nervous system. The GHS-R1a is also present on vagal afferents [15] and some studies initially suggested that ghrelin stimulated food intake exclusively via the vagus nerve [16]. However, another series of highly detailed studies in rodents has shown that gut vagal afferents are not necessary for the orexigenic effect of peripherally injected ghrelin [17]. Thus, it is likely that both circulating ghrelin crossing the blood-brain barrier and ghrelin coming directly from the stomach through the vagus nerve are responsible of the central actions.

This review aims to summarize novel roles of ghrelin in energy balance, focusing particularly on newly identified neuronal pathways mediating the effects of ghrelin, peripheral mechanisms leading to increased adiposity and modulation of the activation of ghrelin.

\section{Ghrelin: Effects in the Central Nervous System}

\section{Role of Ghrelin in the Central Control of Food Intake and Body Weight}

Since the discovery of ghrelin as an orexigenic hormone, the focus of the last decade has been the design of novel molecules to target the ghrelin/GHS-R system for the treatment of obesity. The biological actions of ghrelin are mediated predominantly via the central nervous system pathways controlling food intake, energy expenditure and nutrient partitioning. Rapidly after the discovery of ghrelin as a potent stimulator of GH release [1], it was reported that central injection of ghrelin robustly stimulated feeding in rats [18]. Ghrelin was found to have a limited effect on energy expenditure [19], despite injection directly into the central nervous system resulting in a transient decrease in body temperature [20] and a change in the activity of brown adipose tissue [21].

The orexigenic effect of ghrelin is specifically modulated through the GHS-R, as ghrelin fails to increase feeding behavior in mice lacking this receptor [22]. Among other brain nuclei, GHS-R is expressed in the hypothalamic arcuate nuclei (ARC), a key site in the regulation of energy balance. In the ARC GHS-R co-localizes with two important orexigenic signals, neuropeptide Y (NPY) and agouti-related peptide (AgRP) [23]. Peripheral and central ghrelin administration increases the number of stimulatory synapses on NPY/AgRP neurons [18] at the same time as increasing the number of inhibitory synapses on POMC neurons [24]. NPY and AgRP are crucial for the effect of ghrelin on feeding behavior, with ghrelin failing to increase food intake in mice lacking both NPY and AgRP [25].

Recent findings indicate that nutrient-related metabolic pathways, such as hypothalamic fatty acid metabolism, act as direct modulators of the orexigenic action of ghrelin [26, 27]. Specifically, ghrelin modulates hypothalamic AMP-activated protein kinase (AMPK), a key upstream master regulator of lipid metabolism [26-29]. $\mathrm{Ca}^{2+} /$ calmodulin( $\left.\mathrm{CaM}\right)$-dependent protein kinase kinase 2 (CaMKK2) is expressed predominantly in the central nervous system and activates AMPK. It was demonstrated that ghrelin acts via CaMKK2 to activate hypothalamic AMPK [30]. Consistent with the role of CaMKK2 in energy homeostasis, CaMKK2 null mice exhibited reduced fasting-induced hyperphagia, weighed less and stored less fat when maintained on chow or a high-fat diet [30]. Downstream of CaMKK2, it was demonstrated that the orexigenic effect of ghrelin involves specific inhibition of fatty acid biosynthesis induced by AMPK, resulting in decreased levels of malonyl-CoA and increased carnitine palmitoyltransferase 1 (CPT1) activity in the hypothalamus [27]. In addition, ghrelin also decreases the expression of fatty acid synthase (FAS) specifically in the ventromedial nucleus of the hypothalamus (VMH) [27]. Decreasing AMPK activity in the VMH is sufficient to inhibit the effect of ghrelin on FAS expression and feeding [27]. Thus, these findings demonstrated that, besides its role in maintaining lipid biosynthesis, FAS in the VMH may also have an additional function as a sensor of the nutritional status [27]. In agreement with these data, another report showed that the hypothalamic fatty acid oxidation pathways involving AMPK and CPT1 activated by ghrelin leads to changes in hypothalamic mitochondrial respiration and the production of reactive oxygen species (ROS), which are dependent on uncoupling protein 2 (UCP2) [26]. Thus, the activation of this mitochondrial mechanism is critical for ghrelin-induced activation of NPY/AgRP neurons, and thereby, for ghrelin-induced food intake [26].

Although the hypothalamic ARC appears to be the main site of action of ghrelin on food intake, ghrelin administration into other hypothalamic sites, including the paraventricular nuclei and the lateral hypothalamus [14], and non-hypothalamic sites such as the hindbrain [31] also promotes positive energy balance. Other studies indicate that ghrelin may be acting on neurocircuits similar to those activated by drugs of abuse. As a matter of fact, the GHS-R is also expressed in the ventral tegmental area (VTA), which contains a subpopulation of dopamine neurons that project to forebrain regions such as the ventral striatum, amygdala, prefrontal cortex and hippocampus, where they release dopamine in response to or 


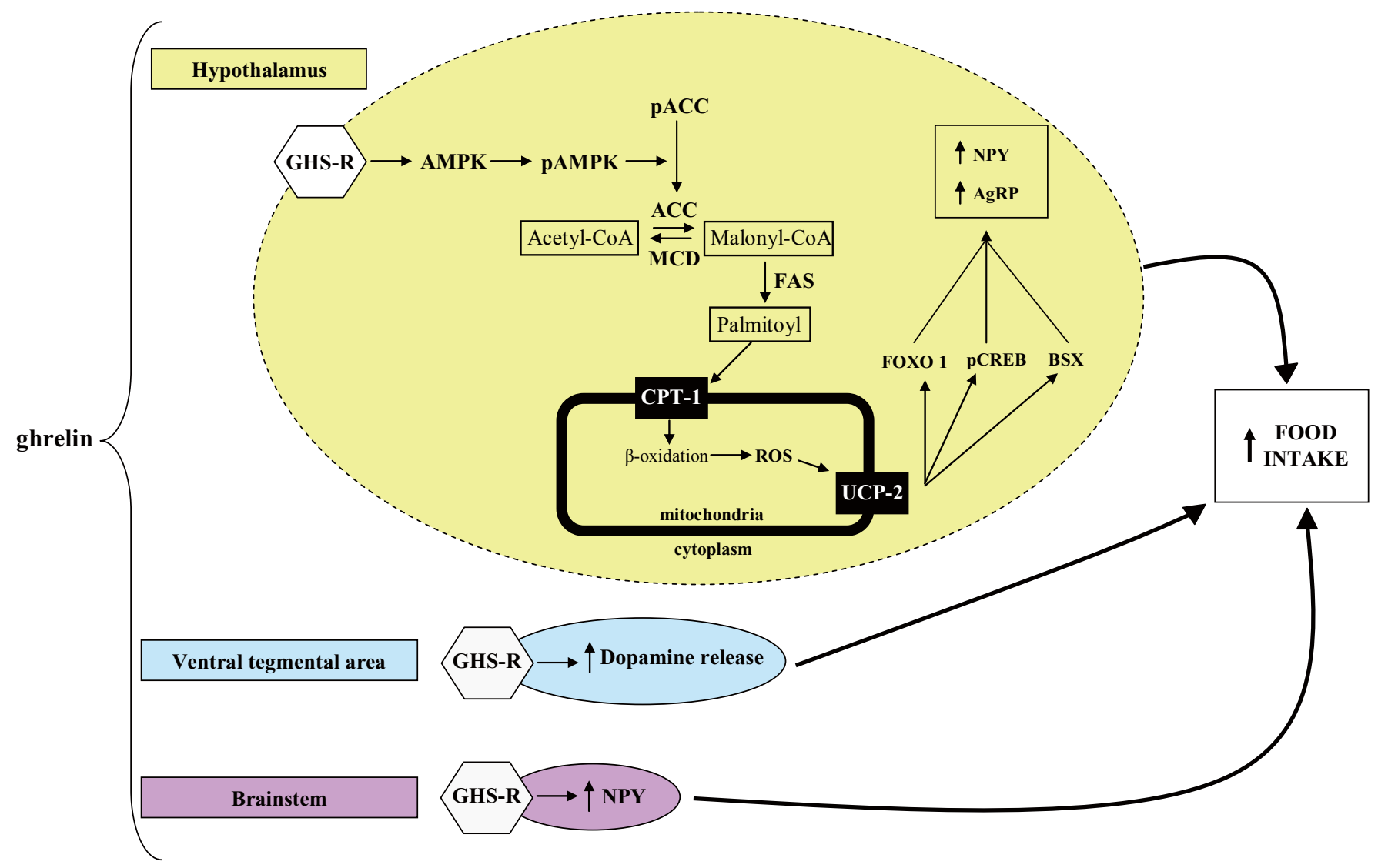

Fig. 1. Different central pathways in the hypothalamus, ventral tegmental area and brainstem are modulating the orexigenic action of ghrelin. The ghrelin receptor (GHS-R) has been located in these areas of the brain and is responsible of the ghrelin-increased food intake.

in anticipation of rewards [32]. This pathway includes the mesolimbic dopaminergic system that is involved in the reinforcement of behavior directed at obtaining natural rewards such as food, mating and social interactions [32]. Some studies have shown that ghrelin binds to the VTA and, when delivered directly onto this region, increases food intake [33, 34]. Consistently, pharmacological blockade of GHS-R in the VTA both decreases rebound feeding responses in fasted mice and eliminates feeding responses produced by peripheral injections of ghrelin [33]. In addition to preclinical data, human studies also show that peripheral ghrelin infusions increase food intake and enhance self reports of hunger and food imagery, particularly imagery for preferred foods [3537]. A functional magnetic resonance imaging study has revealed that i.v. ghrelin administration stimulates the activity of regions that are targets of VTA cells, including the amygdala and nucleus accumbens [38], suggesting that ghrelin is also important in the rewarding qualities and addictive properties of food [39] (fig. 1).

\section{Bsx: A Transcription Factor Mediating the Effects of Ghrelin} The fact that NPY and AgRP are necessary for the orexigenic action of ghrelin was rapidly discovered. However, the molecular mechanisms underlying the regulation of NPY and AgRP by the ghrelin/GHS-R1a system remained unknown for some time. In particular, it was unclear by which specific signals and through what efferent systems the expression of these neuropeptides was regulated to accurately match the bioenergetic needs of the animal. The hypothalamic homeobox domain transcription factor, Bsx, is a crucial player in the central nervous system controlling spontaneous physical activity and the generation of hyperphagic responses [40]. Bsx is expressed in the dorsomedial nuclei of the hypothalamus (DMH) and the ARC and is a master regulator for the hypothalamic expression of key orexigenic neuropeptides, namely NPY and AgRP. This suggests that Bsx may be regulated by afferent signals in response to peripheral energy balance. Ghrelin injection increases Bsx expression in the ARC [41], while leptin challenge attenuates the fasting-induced increase in Bsx levels in the ARC but has no effect in fed rats [41]. Obese leptin-deficient (ob/ob) mice, but not obese melanocortin 4 receptor knockout mice, show higher expression of Bsx, consistent with regulation by the afferent leptin signal, rather than increased adiposity per se [41]. This regulation of Bsx was specific to the ARC as Bsx expression in the DMH was unchanged by leptin or ghrelin [41]. Together, these findings suggest that in the ARC Bsx expression is specifically regulated by afferent energy balance signals and that Bsx mediates the effect of ghrelin on NPY and AgRP [40, 41]. Bsx modulates the stimulatory effect of ghrelin on NPY and $A g R P$ 
gene expression by interacting with other two transcription factors: the phosphorylated cAMP response element binding protein (pCREB) and forkhead box O1 (FoxO1), [40, 42, 43].

In addition to its effects on food intake, Bsx plays also a crucial role in the regulation of locomotor activity, as mice deficient for Bsx lose $50 \%$ of their spontaneous physical activity and fail to increase home cage activity upon food deprivation [40]. Interestingly, mice lacking the GHS-R show a reduction in the anticipatory locomotor response to scheduled meals [44]. This behavioral response to the prediction of food is a critical adaptive feature, and it seems that the ghrelin system is strongly involved in these mechanisms. Therefore, it is tempting to speculate that Bsx might be also mediating the effects of ghrelin on food seeking behavior, but this aspect has not been probed, and further studies will be necessary to elucidate this aspect.

\section{Ghrelin and Adiposity}

Chronic ghrelin administration promotes weight gain and adiposity in rodents [19] in the absence of overfeeding [45]. The body weight gain induced by ghrelin is specifically based on accretion of fat mass without increases in longitudinal skeletal growth or in lean mass [19]. This effect can be explained by a direct action on energy partitioning, which indirectly influences other factors in the energy balance equation. Central ghrelin administration increases the respiratory quotient, indicating decreased utilization of lipids for the generation of energy [45]. For instance, ghrelin infusion stimulates the expression of several fat storage-promoting enzymes and decreases fat oxidation, contributing to ghrelin-induced adiposity [45]. Consistent with the actions of ghrelin on energy balance, the blockade of the GHS-R reduces food intake and fat mass [46], and the neutralization of active ghrelin with specific antibodies reduces food intake and adiposity [47]. The pharmacological actions of ghrelin on energy homeostasis are in agreement with studies performed in ghrelin knockout [48] or GHS-R knockout mice [49], which are protected against early-onset obesity. Importantly, data obtained in humans support the key biological role of ghrelin reported in rodents, with ghrelin stimulating the release of growth hormone [50], subjects with mutations in the GHS-R being shorter [51] and ghrelin administration resulting in feelings of hunger [37]. However, the effect of long-term ghrelin administration in humans has not been tested, and the efficacy of ghrelin antagonists or vaccination against ghrelin in obese patients is also unknown. Indeed, ghrelin levels are low in most of obese patients [52]; however, losing weight by dieting often results in rebound weight gain, and this rebound seems to be in part due to elevated ghrelin levels induced by the initial dieting-associated weight loss [53]. The ghrelin/GHS-R system has been demonstrated to be a successful target in obese rodents. Selective acylated ghrelin blockade by a polyethylene glycol-modified L-RNA oligonu- cleotide promoted weight loss as well as decreased adiposity and food intake in diet-induced obese mice [54]. Therefore, the use of GHS-R blockers seems a plausible valid treatment in pre-obese states or in obese patients showing a rebound weight gain.

\section{Ghrelin and Peripheral Lipid Metabolism}

Ghrelin administered in the third cerebral ventricle (ICV) in rodents decreases BAT sympathetic activity [14]. ICV administration of ghrelin also induces c-fos expression in neurons of the nucleus of the solitary tract and the dorsomotor nucleus of the vagus [14]. Thus, ghrelin activates neurons important in the autonomic nervous system. It is well known that white adipose tissue (WAT) is highly regulated by the autonomic nervous system. Chronic ICV infusion of ghrelin in rats increases lipogenic enzyme expression in WAT, including FAS, SCD-1, ACC and LPL, whereas it decreases the expression of the fat oxidation-promoting carnitoyl-palmitoyl transferase 1 (CPT-1) (fig. 2). These centrally mediated effects of ghrelin on adipocyte metabolism were independent of food intake [14]. Interestingly, central ghrelin does not alter hepatic lipid metabolism, indicating that the effects are tissue-specific. In mice lacking $\beta$-adrenoceptors, central ghrelin administration left body weight unaffected, indicating that ghrelin-induced effects on energy metabolism are mediated via the sympathetic nervous system (SNS) [14].

The innervation of adipose tissue by the SNS is well recognized, and the first neuroanatomical evidence supporting the innervation of WAT by the SNS dates from the end of the 19th century [reviewed in 55]. During the last years, a series of elegant studies performed by the laboratory of Dr. Bartness, injecting a retrograde fluorescent tract tracer into inguinal or epididymal WAT and an anterograde fluorescent tract tracer into the sympathetic chain [56] demonstrated the first molecular neuroanatomical evidence of a brain-WAT cross-talk. Later on, the origin of the SNS outflow from the brain to WAT was investigated by using a transneuronal tract tracer that outlines entire circuits and labels functional chains of hierarchically connected neurons within an animal [57-61]. When this transneuronal tract tracer was administered into the inguinal and epididymal WAT [62], retrograde infected cells were identified throughout the neural axis, including the spinal cord, brainstem, midbrain and forebrain. Interestingly, within the forebrain, several hypothalamic areas that are crucial in the regulation of energy balance, such as the arcuate (ARC), dorsal, paraventricular (PVH), and suprachiasmatic nuclei, as well as the lateral hypothalamic area (LHA) were labelled [62]. As some of those hypothalamic nuclei (ARC) express the GHS-R and others (PVH) are indirect targets of ghrelin, it is plausible to hypothesize that these neuronal populations are mediating the actions of ghrelin on peripheral lipid metabolism. 
Fig. 2. Ghrelin stimulates food intake through its actions on the neuropeptides NPY and AgRP. Independent of its orexigenic effect, ghrelin induces adiposity through the sympathetic nervous system.

Ghrelin promotes lipid deposition in white adipose tissue and liver, but the effects on liver are dependent of food intake.

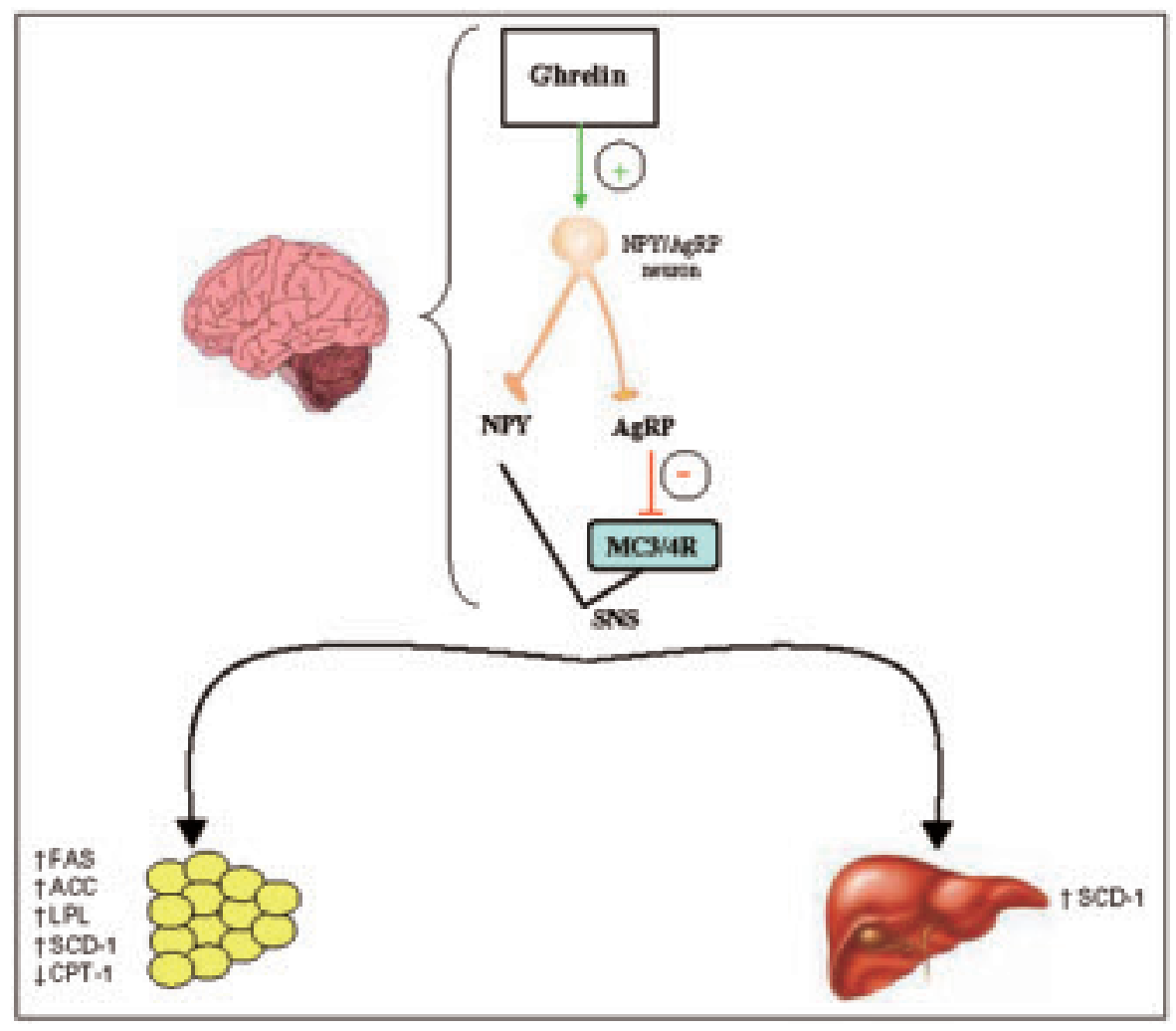

On the other hand, it is well established that ghrelin induces $\mathrm{GH}$ release [1] and that alterations in the $\mathrm{GH}$ axis elicit major changes in fat distribution and mobilization. For example, in patients with GH deficiency or in mice lacking the GH receptor, the percentage of body fat is increased. Thus, it seems probable that the effects of central ghrelin administration on lipid metabolism in lipogenic tissues may be influenced by GH. However, it was shown that chronic ghrelin administration regulates adipose lipid metabolism, mainly in a GH-independent fashion [63]. Central ghrelin also regulates de novo hepatic lipogenesis in a GH-independent fashion but, in contrast, hepatic lipid mobilization is regulated in a GH-dependent fashion [63]. These findings suggested the existence of different ghrelin neuroendocrine circuits regulating adipose tissue and hepatic lipid metabolism.

\section{GOAT}

The enzyme responsible for the octanoylation of ghrelin has recently been identified and characterized simultaneously by two independent groups which initially named it membrane bound $O$-acyltransferase 4 (MBOAT4) and then renamed as ghrelin $O$-acyltransferase (GOAT) and $[64,65]$. In human tissues the levels of GOAT transcripts are high in the stomach and pancreas, with other tissues showing weak expression $[64,65]$. Similar results were obtained in mouse and rodent tissues [64-66], even though GOAT expression was not observed in the pancreas of mice [67]. High levels of $G O A T$ gene expression are found in samples enriched with mouse gastric ghrelin cells, with GOAT expression being highly correlation with ghrelin distribution [68]. The regulation of GOAT mRNA in the stomach is controversial. In one study fasted rats did not show alterations in GOAT levels, whereas prepro-ghrelin mRNA was increased [66]. In contrast a separate study has shown that fasted mice showed decreased gastric GOAT mRNA levels. While plasma acyl ghrelin levels remain unchanged during fasting, desacyl ghrelin levels increase significantly. If in fact neither gastric GOAT mRNA expression nor prepro-ghrelin mRNA expression are up-regulated during fasting, this would point toward the notion that the predominant physiological function of ghrelin is not necessarily, or at least not exclusively, that of a hunger signal reflecting an empty stomach [67]. Together with the lack of effect of nutritional status on gastric GOAT gene expression, GOAT and prepro-ghrelin mRNA levels have also been found to be unchanged in the stomach of $o b / o b$ mice when compared to lean littermates [67]. Finally, chronic caloric restriction only resulted in an increase in gastric GOAT and ghrelin mRNA levels after 3 weeks, when the animals had lost a considerable amount of body weight, but not before [66].

Before GOAT was characterized, it was reported that dietary lipids directly influenced ghrelin acylation [66]. There 


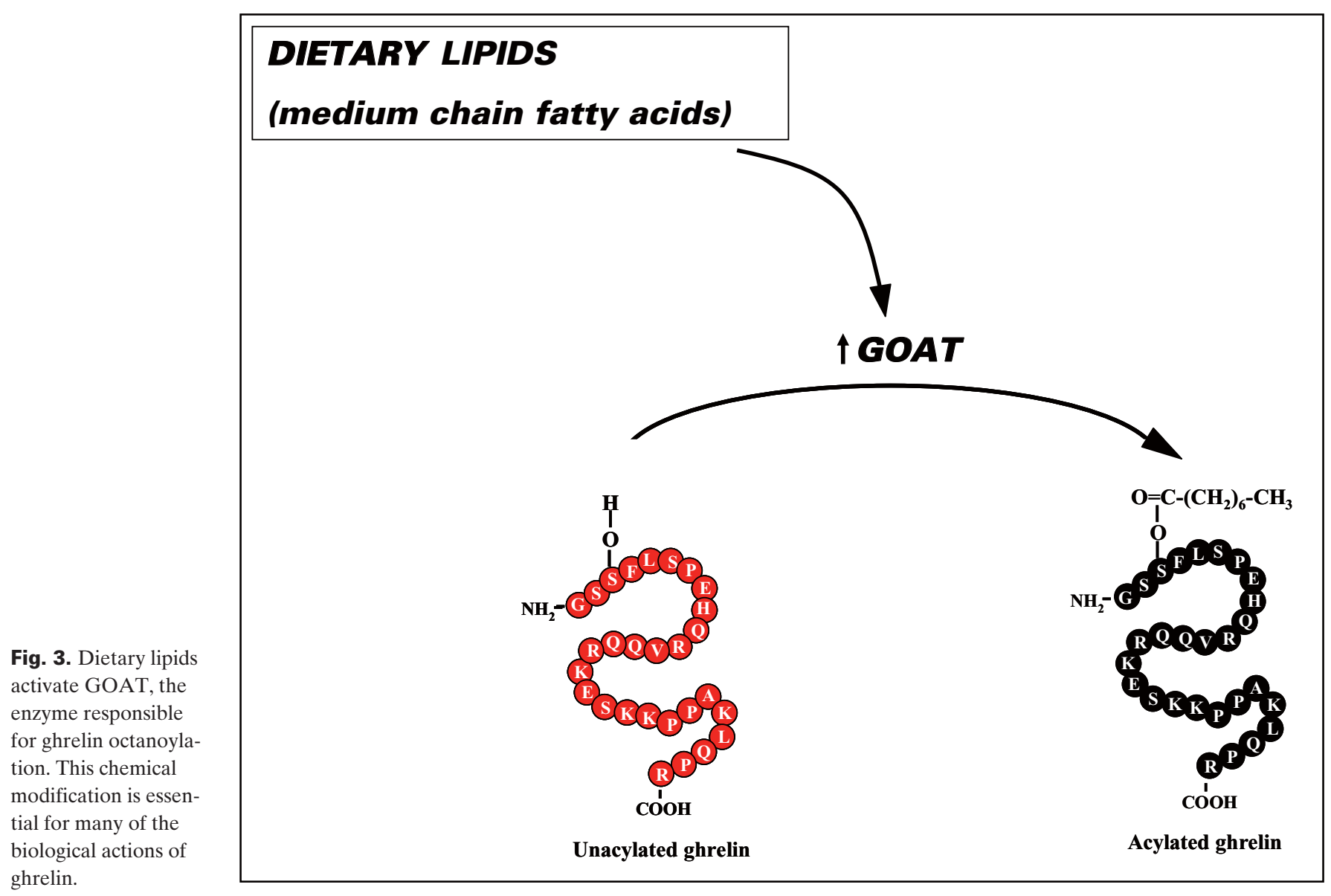

is now evidence that the acylation of ghrelin by GOAT is regulated by nutrient availability and dependent on the presence of specific dietary lipids as acylation substrates [67] (fig. 3). Mice fed with a diet rich in glycerol triheptanoate (a medium-chain triglyceride(MCT)-containing heptanoic acid, which is not synthesized de novo in mice) showed higher levels of acylated ghrelin. GOAT knockout mice are resistant to a high-fat diet (HFD) containing MCT. Although no differences in body composition were found in GOAT-deficient mice fed a HFD, GOAT null mice fed a diet rich in MCT had a lower fat mass, which was probably due to higher energy expenditure during the light cycle [67]. Finally, transgenic mice overexpressing human ghrelin and human GOAT in the liver have been generated. These mice lack octanoyl-modified human ghrelin in the circulation, which is likely due to the absence of medium-chain fatty acids in liver under normal dietary conditions. When the diet was supplemented with triglyceryl octanoate, high concentrations of unacylated and acylated human ghrelin were found in the circulation. Despite having a higher body weight and fat mass the mice overexpressing ghrelin and GOAT had unchanged food intake compared to wild type (WT) mice. This indicates that energy expenditure was significantly lower in transgenic mice than in WT mice. Two weeks after being switched back to a regular chow diet the differences in body weight between transgenic and WT mice disappeared, indicating that the acylation of ghrelin is dependent on dietary lipids [67].

In addition to the forementioned data regarding GOAT and energy homeostasis, GOAT appears also to play a major role in metabolic adaptation in terms of survival in the face of calorie restriction. When subjected to $60 \%$ calorie restriction, WT and GOAT(-/-) mice both lost $30 \%$ of body weight and $75 \%$ of body fat within 4 days. In both lines, fasting blood glucose initially declined equally. After 4 days, glucose stabilized in WT mice at 58-76 mg/dl. In GOAT(-/-) mice, glucose continued to decline, reaching $12-36 \mathrm{mg} / \mathrm{dl}$ on day 7 . At this point, WT mice showed normal physical activity, whereas GOAT(-/-) mice were moribund. GH rose progressively in calorie-restricted WT mice and less in GOAT(-/-) mice. Infusion of either ghrelin or GH normalized blood glucose in GOAT(-/-) mice and prevented death. Thus, an essential function of ghrelin in mice is elevation of $\mathrm{GH}$ levels during severe calorie restriction, thereby preserving blood glucose and preventing death. Taken together these data links acylated ghrelin with $\mathrm{GH}$ and metabolic homeostasis nicely putting together the most relevant biological effects of ghrelin. 


\section{Future Directions}

The discovery of ghrelin in 1999 as a GH secretagogue, and later on as a potent and unique endogenous orexigenic signal, has attracted the attention of many researchers and pharmaceutical companies working in the areas of obesity, diabetes and metabolism. Much effort has made to clarify the effects and mechanisms of action of ghrelin in the central nervous system and peripheral tissues. New roles and aspects of ghrelin physiology are constantly being brought to light. Indeed, all the molecular pathways located downstream of the ghrelin signaling might be possible targets for the development of obesity drugs. However, it is important to note that modifying some of them like AMPK or transcription factors such as Bsx might also affect pathways different to food intake, because they are mediating multiple physiological functions. Des-acylghrelin might be also a target for some aspects related to the metabolic syndrome, but, besides the receptor mediating its biological actions is still unknown, it seems that des-acyl-ghrelin does not affect feeding behavior or body weight. Of all these findings, we believe that the relevance of GOAT must be emphasized. GOAT has the potential to modulate all of the actions of acylated ghrelin leading to important implications in potential development of drugs targeting the acylation process. GOAT is also i) a unique enzyme that acylates ghrelin in a highly conserved manner; ii) ghrelin only binds and activates its receptor GHS-R1a when acylated; and iii) its inhibition or stimulation would not affect physiological processes other than ghrelin acylation, but still preserving the physiological effects of des-acyl-ghrelin.

Methodologies for studying the role and regulation of GOAT are still incomplete, particularly the lack of a specific antibody, assays for measuring activity and GOAT-specific inhibitors or activators. Once these tools are available, our knowledge of the ghrelin/GHS-R1a system will increase considerably and the potential of GOAT-specific pharmacological targets will begin to be fulfilled [69].

\section{Disclosure}

The authors declared no conflict of interest.

\section{References}

1 Kojima M, Hosoda H, Date Y, Nakazato M, Matsuo H, Kangawa K: Ghrelin is a growth-hormonereleasing acylated peptide from stomach. Nature 1999;402:656-660.

2 Tomasetto C, Karam SM, Ribieras S, Masson R, Lefebvre O, Staub A, Alexander G, Chenard MP Rio MC: Identification and characterization of a novel gastric peptide hormone: the motilin-related peptide. Gastroenterology 2000;119:395-405.

> 3 Hosoda H, Kojima M, Matsuo H, Kangawa K: Purification and characterization of rat des-Gln14-ghrelin, a second endogenous ligand for the growth hormone secretagogue receptor. J Biol Chem 2000;275: 21995-22000.

4 Camina JP: Cell biology of the ghrelin receptor. J Neuroendocrinol 2006;18:65-76.

$\checkmark 5$ Gauna C, Delhanty PJ, van Aken MO, Janssen JA, Themmen AP, Hofland LJ, Culler M, Broglio F, Ghigo E, van der Lely AJ: Unacylated ghrelin is active on the INS-1e rat insulinoma cell line independently of the growth hormone secretagogue receptor type 1a and the corticotropin releasing factor 2 receptor. Mol Cell Endocrinol 2006;251:103-111.

6 Granata R, Settanni F, Biancone L, Trovato L, Nano R, Bertuzzi F, Destefanis S, Annunziata M, Martinetti M, Catapano F, Ghe C, Isgaard J, Papotti M, Ghigo E, Muccioli G: Acylated and unacylated ghrelin promote proliferation and inhibit apoptosis of pancreatic beta-cells and human islets: Involvement of 3',5'-cyclic adenosine monophosphate/protein kinase a, extracellular signal-regulated kinase 1/2, and phosphatidyl inositol 3-kinase/ Akt signaling. Endocrinology 2007;148:512-529.

7 Halem HA, Taylor JE, Dong JZ, Shen Y, Datta R, Abizaid A, Diano S, Horvath TL, Culler MD: A novel growth hormone secretagogue-1a receptor antagonist that blocks ghrelin-induced growth hormone secretion but induces increased body weight gain. Neuroendocrinology 2005;81:339-349.
Zhang JV, Ren PG, Avsian-Kretchmer O, Luo CW, Rauch R, Klein C, Hsueh AJ: Obestatin, a peptide encoded by the ghrelin gene, opposes ghrelin's effects on food intake. Science 2005;310:996-999.

9 Nogueiras R, Pfluger P, Tovar S, Arnold M, Mitchell S, Morris A, Perez-Tilve D, Vazquez MJ, Wiedmer P, Castaneda TR, DiMarchi R, Tschop M, Schurmann A, Joost HG, Williams LM, Langhans W, Dieguez C: Effects of obestatin on energy balance and growth hormone secretion in rodents. Endocrinology 2007;148:21-26.

10 Seoane LM, Al-Massadi O, Pazos Y, Pagotto U, Casanueva FF: Central obestatin administration does not modify either spontaneous or ghrelin-induced food intake in rats. J Endocrinol Invest 2006; 29:RC13-15

11 Gourcerol G, St-Pierre DH, Tache Y: Lack of obestatin effects on food intake: Should obestatin be renamed ghrelin-associated peptide (GAP)? Regul Pept 2007;141:1-7.

12 Gourcerol G, Tache Y: Obestatin - a ghrelinassociated peptide that does not hold its promise to suppress food intake and motility. Neurogastroenterol Motil 2007;19:161-165.

13 Gualillo O, Lago F, Gomez-Reino J, Casanueva FF, Dieguez C: Ghrelin, a widespread hormone: insights into molecular and cellular regulation of its expression and mechanism of action. FEBS Lett 2003;552:105-109.

14 van der Lely AJ, Tschop M, Heiman ML, Ghigo E: Biological, physiological, pathophysiological, and pharmacological aspects of ghrelin. Endocr Rev 2004;25:426-457.

15 Date Y, Murakami N, Toshinai K, Matsukura S, Niijima A, Matsuo H, Kangawa K, Nakazato M: The role of the gastric afferent vagal nerve in ghrelin-induced feeding and growth hormone secretion in rats. Gastroenterology 2002;123:1120-1128.
6 Asakawa A, Inui A, Kaga T, Yuzuriha H, Nagata T, Ueno N, Makino S, Fujimiya M, Niijima A, Fujino MA, Kasuga M: Ghrelin is an appetite-stimulatory signal from stomach with structural resemblance to motilin. Gastroenterology 2001;120:337-345.

17 Arnold M, Mura A, Langhans W, Geary N: Gut vagal afferents are not necessary for the eatingstimulatory effect of intraperitoneally injected ghrelin in the rat. J Neurosci 2006;26:11052-11060.

18 Nakazato M, Murakami N, Date Y, Kojima M, Matsuo H, Kangawa K, Matsukura S: A role for ghrelin in the central regulation of feeding. Nature 2001; 409:194-198.

19 Tschop M, Smiley DL, Heiman ML: Ghrelin induces adiposity in rodents. Nature 2000;407:908-913.

20 Lawrence CB, Snape AC, Baudoin FM, Luckman SM: Acute central ghrelin and GH secretagogues induce feeding and activate brain appetite centers. Endocrinology 2002;143:155-162.

21 Date Y, Shimbara T, Koda S, Toshinai K, Ida T, Murakami N, Miyazato M, Kokame K, Ishizuka Y, Ishida Y, Kageyama H, Shioda S, Kangawa K, Nakazato M: Peripheral ghrelin transmits orexigenic signals through the noradrenergic pathway from the hindbrain to the hypothalamus. Cell Metab 2006;4: 323-331.

22 Sun Y, Wang P, Zheng H, Smith RG: Ghrelin stimulation of growth hormone release and appetite is mediated through the growth hormone secretagogue receptor. Proc Natl Acad Sci U S A 2004;101: 4679-4684.

23 Willesen MG, Kristensen P, Romer J: Co-localization of growth hormone secretagogue receptor and NPY mRNA in the arcuate nucleus of the rat. Neuroendocrinology 1999;70:306-316. 
24 Cowley MA, Smith RG, Diano S, Tschop M, Pronchuk N, Grove KL, Strasburger CJ, Bidlingmaier M, Esterman M, Heiman ML, Garcia-Segura LM, Nillni EA, Mendez P, Low MJ, Sotonyi P, Friedman JM, Liu H, Pinto S, Colmers WF, Cone RD, Horvath TL: The distribution and mechanism of action of ghrelin in the CNS demonstrates a novel hypothalamic circuit regulating energy homeostasis. Neuron 2003;37:649-661.

25 Chen HY, Trumbauer ME, Chen AS, Weingarth DT, Adams JR, Frazier EG, Shen Z, Marsh DJ, Feighner SD, Guan XM, Ye Z, Nargund RP, Smith RG, Van der Ploeg LH, Howard AD, MacNeil DJ, Qian S: Orexigenic action of peripheral ghrelin is mediated by neuropeptide Y and agouti-related protein. Endocrinology 2004;145:2607-2612.

26 Andrews ZB, Liu ZW, Wallingford N, Erion DM, Borok E, Friedman JM, Tschop MH, Shanabrough M, Cline G, Shulman GI, Coppola A, Gao XB, Horvath TL, Diano S: Ucp2 mediates ghrelin's action on NPY/AgRP neurons by lowering free radicals. Nature 2008;454:846-851.

27 Lopez M, Lage R, Saha AK, Perez-Tilve D, Vazquez MJ, Varela L, Sangiao-Alvarellos S, Tovar S, Raghay K, Rodriguez-Cuenca S, Deoliveira RM, Castaneda T, Datta R, Dong JZ, Culler M, Sleeman MW, Alvarez CV, Gallego R, Lelliott CJ, Carling D, Tschop MH, Dieguez C, Vidal-Puig A: Hypothalamic fatty acid metabolism mediates the orexigenic action of ghrelin. Cell Metab 2008;7:389-399.

28 Kola B, Farkas I, Christ-Crain M, Wittmann G, Lolli F, Amin F, Harvey-White J, Liposits Z, Kunos G, Grossman AB, Fekete C, Korbonits $\mathrm{M}$ : The orexigenic effect of ghrelin is mediated through central activation of the endogenous cannabinoid system. PLoS ONE 2008;3:e1797.

29 Andersson U, Filipsson K, Abbott CR, Woods A, Smith K, Bloom SR, Carling D, Small CJ: AMPactivated protein kinase plays a role in the contro of food intake. J Biol Chem 2004;279:12005-12008.

-30 Anderson KA, Ribar TJ, Lin F, Noeldner PK, Green MF, Muehlbauer MJ, Witters LA, Kemp BE, Means AR: Hypothalamic CaMKK2 contributes to the regulation of energy balance. Cell Metab 2008;7:377-388.

-31 Faulconbridge LF, Cummings DE, Kaplan JM, Grill HJ: Hyperphagic effects of brainstem ghrelin administration. Diabetes 2003;52:2260-2265.

32 Wise RA: Dopamine, learning and motivation. Nat Rev Neurosci 2004;5:483-494.

33 Abizaid A, Liu ZW, Andrews ZB, Shanabrough M, Borok E, Elsworth JD, Roth RH, Sleeman MW, Picciotto MR, Tschop MH, Gao XB, Horvath TL: Ghrelin modulates the activity and synaptic input organization of midbrain dopamine neurons while promoting appetite. J Clin Invest 2006;116:3229-3239.

\$3 Naleid AM, Grace MK, Cummings DE, Levine AS: Ghrelin induces feeding in the mesolimbic reward pathway between the ventral tegmental area and the nucleus accumbens. Peptides 2005;26:2274-2279.

\35 Cummings DE, Frayo RS, Marmonier C, Aubert R, Chapelot D: Plasma ghrelin levels and hunger scores in humans initiating meals voluntarily without time- and food-related cues. Am J Physiol Endocrinol Metab 2004;287:E297-304.

-36 Schmid DA, Held K, Ising M, Uhr M, Weikel JC, Steiger A: Ghrelin stimulates appetite, imagination of food, GH, ACTH, and cortisol, but does not affect leptin in normal controls. Neuropsychopharmacology 2005;30:1187-1192.

\37 Wren AM, Seal LJ, Cohen MA, Brynes AE, Frost GS, Murphy KG, Dhillo WS, Ghatei MA, Bloom SR: Ghrelin enhances appetite and increases food intake in humans. J Clin Endocrinol Metab 2001; 86:5992.
38 Malik S, McGlone F, Bedrossian D, Dagher A: Ghrelin modulates brain activity in areas that control appetitive behavior. Cell Metab 2008;7:400-409.

39 Jerlhag E, Egecioglu E, Dickson SL, Andersson M, Svensson L, Engel JA: Ghrelin stimulates locomotor activity and accumbal dopamine-overflow via central cholinergic systems in mice: implications for its involvement in brain reward. Addict Biol 2006; 11:45-54.

40 Sakkou M, Wiedmer P, Anlag K, Hamm A, Seuntjens E, Ettwiller L, Tschop MH, Treier M: A role for brain-specific homeobox factor Bsx in the control of hyperphagia and locomotory behavior. Cell Metab 2007;5:450-463.

41 Nogueiras R, Lopez M, Lage R, Perez-Tilve D, Pfluger P, Mendieta-Zeron H, Sakkou M, Wiedmer P, Benoit SC, Datta R, Dong JZ, Culler M, Sleeman M, Vidal-Puig A, Horvath T, Treier M, Dieguez C, Tschop MH: Bsx, a novel hypothalamic factor linking feeding with locomotor activity, is regulated by energy availability. Endocrinology 2008;149:3009-3015.

42 Shimizu-Albergine M, Ippolito DL, Beavo JA: Downregulation of fasting-induced camp response element-mediated gene induction by leptin in neuropeptide Y neurons of the arcuate nucleus. J Neurosci 2001;21:1238-1246.

43 Kitamura T, Feng Y, Kitamura YI, Chua SC Jr, Xu AW, Barsh GS, Rossetti L, Accili D: Forkhead protein foxo1 mediates AgRP-dependent effects of leptin on food intake. Nat Med 2006;12:534-540.

44 Blum ID, Patterson Z, Khazall R, Lamont EW, Sleeman MW, Horvath TL, Abizaid A: Reduced anticipatory locomotor responses to scheduled meals in ghrelin receptor deficient mice. Neuroscience 2009;164:351-359.

45 Theander-Carrillo C, Wiedmer P, Cettour-Rose P, Nogueiras R, Perez-Tilve D, Pfluger P, Castaneda TR, Muzzin P, Schurmann A, Szanto I, Tschop MH, Rohner-Jeanrenaud F: Ghrelin action in the brain controls adipocyte metabolism. J Clin Invest 2006;116:1983-1993.

46 Shuto Y, Shibasaki T, Otagiri A, Kuriyama H, Ohata H, Tamura H, Kamegai J, Sugihara H, Oikawa S, Wakabayashi I: Hypothalamic growth hormone secretagogue receptor regulates growth hormone secretion, feeding, and adiposity. J Clin Invest 2002;109:1429-1436.

47 Zorrilla EP, Iwasaki S, Moss JA, Chang J, Otsuji J, Inoue K, Meijler MM, Janda KD: Vaccination against weight gain. Proc Natl Acad Sci U S A 2006;103:13226-13231.

48 Wortley KE, Anderson KD, Garcia K, Murray JD, Malinova L, Liu R, Moncrieffe M, Thabet K, Cox HJ, Yancopoulos GD, Wiegand SJ, Sleeman MW: Genetic deletion of ghrelin does not decrease food intake but influences metabolic fuel preference. Proc Natl Acad Sci U S A 2004;101:8227-8232.

49 Zigman JM, Nakano Y, Coppari R, Balthasar N, Marcus JN, Lee CE, Jones JE, Deysher AE, Waxman AR, White RD, Williams TD, Lachey JL, Seeley RJ, Lowell BB, Elmquist JK: Mice lacking ghrelin receptors resist the development of dietinduced obesity. J Clin Invest 2005;115:3564-3572.

50 Seoane LM, Tovar S, Baldelli R, Arvat E, Ghigo E, Casanueva FF, Dieguez C: Ghrelin elicits a marked stimulatory effect on GH secretion in freely-moving rats. Eur J Endocrinol 2000;143:R7-9.

51 Pantel J, Legendre M, Cabrol S, Hilal L, Hajaji Y, Morisset S, Nivot S, Vie-Luton MP, Grouselle D, de Kerdanet M, Kadiri A, Epelbaum J, Le Bouc Y, Amselem S: Loss of constitutive activity of the growth hormone secretagogue receptor in familial short stature. J Clin Invest 2006;116:760-768.
52 Tschop M, Weyer C, Tataranni PA, Devanarayan V, Ravussin E, Heiman ML: Circulating ghrelin levels are decreased in human obesity. Diabetes 2001;50:707-709.

53 Cummings DE, Weigle DS, Frayo RS, Breen PA, Ma MK, Dellinger EP, Purnell JQ: Plasma ghrelin levels after diet-induced weight loss or gastric bypass surgery. N Engl J Med 2002;346:1623-1630.

54 Shearman LP, Wang SP, Helmling S, Stribling DS Mazur P, Ge L, Wang L, Klussmann S, Macintyre DE, Howard AD, Strack AM: Ghrelin neutralization by a ribonucleic acid-SPM ameliorates obesity in diet-induced obese mice. Endocrinology 2006;147:1517-1526.

55 Bartness TJ, Bamshad M: Innervation of mammalian white adipose tissue: implications for the regulation of total body fat. Am J Physiol 1998;275: R1399-1411.

56 Youngstrom TG, Bartness TJ: Catecholaminergic innervation of white adipose tissue in Siberian hamsters. Am J Physiol 1995;268:R744-751.

57 Bartness TJ, Kay Song C, Shi H, Bowers RR, Foster MT: Brain-adipose tissue cross talk. Proc Nutr Soc 2005;64:53-64

58 Bartness TJ, Song CK: Brain-adipose tissue neural crosstalk. Physiol Behav 2007;91:343-351.

59 Bartness TJ, Song CK: Thematic review series: Adipocyte biology. Sympathetic and sensory innervation of white adipose tissue. J Lipid Res 2007;48: $1655-1672$.

60 Card JP, Rinaman L, Schwaber JS, Miselis RR, Whealy ME, Robbins AK, Enquist LW: Neurotropic properties of pseudorabies virus: uptake and transneuronal passage in the rat central nervous system. J Neurosci 1990;10:1974-1994.

61 Strack AM, Loewy AD: Pseudorabies virus: a highly specific transneuronal cell body marker in the sympathetic nervous system. J Neurosci 1990;10: 2139-2147.

62 Bamshad M, Aoki VT, Adkison MG, Warren WS, Bartness TJ: Central nervous system origins of the sympathetic nervous system outflow to white adipose tissue. Am J Physiol 1998;275:R291-299.

63 Sangiao-Alvarellos S, Vazquez MJ, Varela L, Nogueiras R, Saha AK, Cordido F, Lopez M, Dieguez C: Central ghrelin regulates peripheral lipid metabolism in a growth hormone-independent fashion. Endocrinology 2009;150:4562-4574.

64 Gutierrez JA, Solenberg PJ, Perkins DR, Willency JA, Knierman MD, Jin Z, Witcher DR, Luo S, Onyia JE, Hale JE: Ghrelin octanoylation mediated by an orphan lipid transferase. Proc Natl Acad Sci U S A 2008;105:6320-6325.

65 Yang J, Brown MS, Liang G, Grishin NV, Goldstein JL: Identification of the acyltransferase that octanoylates ghrelin, an appetite-stimulating peptide hormone. Cell 2008;132:387-396.

66 Gonzalez CR, Vazquez MJ, Lopez M, Dieguez C: Influence of chronic undernutrition and leptin on goat mRNA levels in rat stomach mucosa. J Mol Endocrinol 2008;41:415-421.

67 Kirchner H, Gutierrez JA, Solenberg PJ, Pfluger PT, Czyzyk TA, Willency JA, Schurmann A, Joost HG Jandacek RJ, Hale JE, Heiman ML, Tschop MH: Goat links dietary lipids with the endocrine control of energy balance. Nat Med 2009;15:741-745.

68 Sakata I, Yang J, Lee CE, Osborne-Lawrence S, Rovinsky SA, Elmquist JK, Zigman JM: Colocalization of ghrelin $\mathrm{O}$-acyltransferase and ghrelin in gastric mucosal cells. Am J Physiol Endocrinol Metab 2009;297:E134-141.

69 Romero A, Kirchner H, Heppner K, Pfluger PT, Tschöp MH, Nogueiras R: GOAT: the master switch for the ghrelin system? Eur J Endocrinol 2010;163:1-8. 